\title{
The Master Film is a Western : The Mythology of the American West in the Cities of the Red Night Trilogy
}

Michael J. Prince

\author{
(2) OpenEdition \\ Journals \\ Electronic version \\ URL: https://journals.openedition.org/ejas/9412 \\ DOI: $10.4000 /$ ejas. 9412 \\ ISSN: 1991-9336 \\ Publisher \\ European Association for American Studies
}

Electronic reference

Michael J. Prince, "The Master Film is a Western : The Mythology of the American West in the Cities of the Red Night Trilogy", European journal of American studies [Online], 6-3 | 2011, document 3, Online since 03 November 2011, connection on 08 July 2021. URL: http://journals.openedition.org/ejas/9412 ; DOI: https://doi.org/10.4000/ejas.9412

This text was automatically generated on 8 July 2021.

Creative Commons License 


\title{
The Master Film is a Western : The Mythology of the American West in the Cities of the Red Night Trilogy
}

\author{
Michael J. Prince
}

\section{Introduction}

William S. Burroughs's innovative and sometimes off-putting textual techniques can be read as part of a satiric project, one that participates obliquely in Black Humor, but, particularly toward the end of his career, may suggest a respite from the hopelessness, helplessness, and skepticism inflicted by the power structures it describes and denounces. His work articulates complex responses to conspiracies of alien invasions and their cruel machinations through social power structures, chief among these being church and state. His skepticism to language is well known (Morgan 71-72; Burroughs, "Technology" 35), and much criticism on Burroughs describes disruptions at the level of sentence (such as employment of "cut-ups") and in the kaleidoscopic sequences of vignettes referred to by Burroughs scholars as "routines." But this challenge to the power of representation also extends to a broader field of discourse, that of cultural myth. Burroughs's application of myth metanarratives ultimately critiques the psychic and societal limitations they impose. The dubious enchantment of cultural myth dominates the Cities of the Red Night trilogy, ${ }^{1}$ but particularly the second novel, The Place of Dead Roads, demonstrates that the myth of the American West serves both the powers of hegemony and resistance. Indeed, a virulent cultural myth typically renders cognitive and teleological service to both sides over an ideological divide (Slotkin, Gunfighter 586-91). In this novel, the mythology of the American West is employed in the development and empowerment of the protagonist, Kim Carsons, but at the same time it demonstrates the entrapping qualities of cultural myth.

1 In particular, the mythology of the American West contributes to a potential liberation scenario. A major tactic in the struggle for liberation in The Place of Dead Roads is the warping, splicing and destruction of the narrative myth fabric, developed 
metaphorically as the "Master Film." By the end of the trilogy, as Timothy Murphy suggests, the future negotiation of what it is to be human and a citizen may be deferred, articulated not by exemplars but through a highlighting of tensions within the individual (198-99). The metanarratives supporting previous historical and social orders are provisionally bracketed as an essential first step in the renegotiation process, and subsequently counterposed to improbable "presents and not-necessarilytrue pasts" in which a new subjectivity "becomes possible" (170). As Murphy sees it, this is one way in which Burroughs's work shows a "commitment to social transformation in the face of the postmodern evacuation of the political sphere" (2).

2 This essay will trace the vestiges of the Western literary and cinematic tropes in Cities of the Red Night; then expand the development of the Master Film and the dominance of the Western genre in The Place of Dead Roads; and finally discuss some faint echoes of the mythology of the American West in the last book, The Western Lands. I am suggesting a development from a casual employment of pulp fiction and cinematic tropes, via references and "routines," towards a more deliberate depiction of the Western (and its Depression era twin, the Gangster narrative) as a central pivot to the protagonist Kim Carsons's character formation as self-actualized gay-shootist and "social bandit," and to establish the "Master Film" that Carsons both subsumes and resists as a Western. From its nascent stirrings in the first book, to a dominant superstructure upon which the protagonist develops in the second, to incidental ironic parody in the last, the Master Film as Western anchors the narrative while it functions as a metaphor for the extreme naturalizing function of cultural myth, for good or ill.

\section{Myth, History, and Genre of the American Frontier}

Within the trilogy, many instances of plot, character, setting, and dialect can be identified with the Western genre, along with characteristic features of dialogue, narration, and reported speech. These myth symbols, icons, and tropes have been developed and discussed as a significant American cultural myth from the middle of the twentieth-century to the present. ${ }^{2}$ But the mythology most relevant for this paper, and the one most actively interrogated by Burroughs, was first enunciated in its succinct form by Theodore Roosevelt in The Winning of the West. This version of the myth has been thoroughly analyzed and discussed by historian and critic Richard Slotkin in Gunfighter Nation. Slotkin describes a defining national "Progressive myth" derived from Roosevelt's historical theory, that the Western frontier tried, tested, and improved the Anglo-Saxon race through savage warfare with the Indians, a narrative which highlights the virile aspect of a "regeneration through violence" dynamic. But more importantly than texts participating in the discourse of history, popular genres persistently carry cultural mythology, and that has certainly been the case with the myth of the American West (Slotkin, Gunfighter 10-16, 29-35).

3 In the first book of Burroughs's trilogy, Cities of the Red Night, the story is told through a rotation of the popular genres of the sea story, detective story, and to a lesser degree, a science fiction narrative. The next novel, The Place of Dead Roads, is more narratively stable, but as this paper will show, this is for a deliberate purpose. As David Glover has pointed out, to claim that this novel is a Western is an oversimplification. However, allowing for some digression and overlap, The Place of Dead Roads invokes and interrogates potential conflicts and solutions chiefly with the aid of the Western genre. 
Other genres, such as "hard boiled" gangster fiction, the spy novel, and some vestiges of science fiction are also called upon (Glover 209-11). This list of attendant genres indicates that these novels deliberately sample well-worn popular culture tropes, serving as they do so to set up the broader metaphor of the Master Film as a worlddefining cultural myth. In The Place of Dead Roads, the master Master Film is unequivocally the Western, centered as it is on the shootist Kim Carsons as the "hero." This book deserves particular attention in this study, for the myth of the American West both empowers and entraps Carsons, thus Burroughs offers a cautionary critique of the allure and sway of cultural myth. In the last book, The Western Lands, the unsolved assassination of Carsons is resolved in such a way that it provides a further critique of the Western as Master Film and reigning American cultural myth, as well as questioning the psychic or cognitive hegemony of any cultural myth.

The possibility of a Western parody combined with the concerns of cultural myth and their attendant narratives and symbols, which has been on the agenda of satiric articulations since Nathanael West, opens up The Place of Dead Roads, as well as Burroughs's other books, to a satiric reading. Burroughs's work fits, at times comfortably, with what Steven Weisenburger calls "degenerative satire." The "conditions" of degenerative satire are a "mega-bureaucracy and its blindly progressive 'information society.' [...] The human subject seems merely a site occupied by various discourses before being swept aside by terrifying, impersonal forces." However, "[the] best of them demonstrate that no one [...] is ever really stripped of her power over those messages that continually relocate one as sender, referent, and addressee. In short, there are norms operating in these texts," only, they are "nomadic" and "without truth-value" (6). Characteristic of degenerative satire is "extreme grotesqueness of imagery," "carnivalesque instability of [...] narrative viewpoint," "juxtaposition of high culture with vernacular stuff," "structural inversion of mythic progress," and a degree of play that results in "transtextuality" that invariably drags in references that the reader may have (Weisenburger 8). In response to negative criticisms of contemporary fiction, the postmodern novel has been recognized by Weisenburger as essentially satiric in method and aims, due to-and not in spite of-the difficulty of representing "fact," much less "truth." Timothy S. Murphy's sanguine claims for a notion of Deleuzean empowerment in the Cities of the Red Night trilogy (Murphy 200) also recommend them as postmodern satire. The Master Film metaphor in Burroughs's trilogy, then, embraces and plays off of this problem of representation. The multi-layered narrative gyrations typical of Burroughs's best work deal directly with this issue. But instead of bemoaning a loss of center, his work exploits this loss, and celebrates it.

5 One de-centering strategy is the assortment of elements borrowed from various genres in terms of plot, dialogue, setting, and via intertextual and extratextual allusions. Film and cultural myth are here employed initially as articulations derived from a culturally contingent repertoire of available symbolic patterns. But due to extreme juxtaposition, and a sometimes rapid cycling through obliquely related "routines," the cultural myth references frequently appear as discreet items, making the respective metanarratives appear as if they were sampled. Indeed, in his essay "Les Voleurs," Burroughs happily confesses that he employs wholesale theft of words and phrases, in part to "abandon the fetish of originality" (20). 
The overriding narrative strategies in these books sample a genre-set that historically has been heavily engaged in the ideological tensions and class struggles that have broadly played out in the United States from the Civil War to the 1920s as the "populist" vs. "progressive" conflict, the former underwriting an agrarian egalitarianism, the latter iterating the societal hegemony of capital via corporate power. The dime novels from 1840 to 1875 were in the main frontier stories based on contemporary Western scenarios or the American Revolution; those after 1875 shifted to "outlaws" and "detectives," featuring the fictional Deadwood Dick, and the historical Jesse James. The James Gang and the Younger Brothers became nationally renowned in their conflicts with the railroads; they were the subjects of at least two sensational but factually based books from 1880 to 1882, framing the Glendale Train Robbery and the assassination of Jesse James (Slotkin, Gunfighter 125-39). But it is as legend and fiction that James inflates to mythical proportions so that by 1883 the United States "Postmaster General forced the temporary withdrawal of the James Boys series" (128). Another "social bandit," Billy the Kid, also participates in the same anti-Capital, antiEstablishment mythology (Brown 398). Through the references to lawman, Pat Garrett, and the weight given to Billy the Kid's last words, "Quién Es?", his assassination is a redolent subtext in The Place of Dead Roads. And Burroughs's employment of a protagonist, Kim Carsons, who aspires to the "social bandit" is no coincidence.

7 Richard Slotkin shows how the Western Hero has migrated into attendant genres, morphing slightly in transit. The figure of Deadwood Dick as an "outlaw detective" primes the way for the hard-boiled detective story in pre-1940s pulp fiction to "[address] the problem of adapting the traditional concept of democratic heroism, based on the Myth of the Frontier, to a post-Frontier America" (Gunfighter 194). The populist Libertarianism of the first novel in the Burroughs trilogy is represented in the Caribbean pirate narrative, and especially, in the adventures of Clem Snide, private detective, indicating an ideological as well as genre-based link. And since the last book, The Western Lands, continues with a resolution of the unresolved elements in The Place of Dead Roads, protagonists spanning all three books-boy pirate Noah Blake, private detective Clem Snide, social bandit Kim Carsons, and technician Joe the Deadstructurally invoke the unresolved social tensions represented by the mythic west in popular fiction and film.

While the notion of the "Master Film," along with the threat of its dominating discourse, is not presented until the second novel, evidence of its function and awareness of its qualities are present in Cities of the Red Night. Indeed, the first chapter concludes with italicized stage directions complete with cues for lighting and sound effects (11). A strategy of parallel narratives and unrelenting aleatory sampling of the tropes of cinematic and literary violence anticipate the later revelation of the Master Film in The Place of Dead Roads. In the first book, however, the references are usually casual, suggestive whispers dropped in the reader's ear, for instance allusions to war films: "Yeah. It's the old army game from here to eternity" (Cities,95), "some stinker of a battleship film" (207); or dialogue derived from classic American literature: "still it's a bit confining, old sport" from Fitzgerald's Gatsby (182), and "God bless Captain Krup" (213), mocking dialogue from Melville's Billy Budd. And, as a natural part of the available cultural cues, the mythology of the American West is also referenced via the title of Owen Wister's 1902 novel: “The pimply virgin there trying to act wise-he's 
from Virginia, so we call him the Virginian" (215), a specific reference that returns with more intensity in the following volume.

In Cities of the Red Night, Clem Snide and the Gobi Desert vigilante, Audrey Carsons, are even more suggestive of the Frontier Myth. If it is the case, as Slotkin argues, that "the hard-boiled detective" is a "frontier hero" (Slotkin, Gunfighter 228), Clem Snide fits the bill. In particular, the chapter titles in which his narrative strain occurs invoke the West or the Western. When Snide goes to Athens in search of his quarry, the chapter is entitled "Horse Hattock to Ride to Ride" (Cities 79). By removing the conjunction from the call "Horse and hattock," from Sir Walter Scott's The Black Dwarf, the phrase suggests a character name, one that conflates Scott's national romanticism with American Western folklore. And the next Clem Snide chapter bears the title "Quién Es?" (113), anticipating the closing section of The Place of Dead Roads with a direct citation of Billy the Kid's last words. The introduction of "Audrey" (echoing the Singing Cowboy Gene Autry) in the chapter "A Cowboy in the Seven-days-a-week Fight" superimposes upon the ancient cityscape of Tamaghis a Western frontier town with the ruthless exigencies of vigilante frontier justice: "The Spermers [...] are outlaws who may be killed by any citizen, like cattle rustlers" (Cities 176). Audrey brandishes a "spark gun," and he and sidekick Cupid Mount Etna resolve an attack with a gunfight (177-78), much as would Kim Carsons in the next novel.

10 However, in Cities of the Red Night the mythic west rarely, if ever, is represented in a "pure" form. Burroughs's agenda is to displace the hegemony of any one master narrative, and therefore tropes from diverse myth repertoires are conflated, but in such a way that each still retains some vestige of its discursive source-the desired effect is not one totalizing master narrative, but rather an ensemble where the desire for totality is contrasted with the persistence of the multiplicity:

Farnsworth, Ali, and Noah Blake are moving south across the Red Desert, a vast area of plateaus, canyons, and craters where sandstone mesas rise from the red sand. The temperature is moderate even at midday and they travel naked except for desert boots, packs, and belts with eighteen-inch Bowie knives and ten-shot revolvers chambered for a high-speed 22-caliber cartridge. They have automatic carbines of the same caliber in their packs, with thirty-shot clips. These weapons may be needed if a time warp dumps an old western posse in their laps. (218)

Character, setting and implicit plot all participate in the mythic west, but not only in the mythic west. Burroughs first spins out a mixed catalogue of character namesAnglo-Saxon, Muslim, Anglo-Saxon. Likewise, in the desertscape are the tell-tale indications of Monument Valley, the perennial setting of the Western cinema. But this can not be, for the narrative's declared setting here is in the province of the Gobi desert. The accoutrements also demonstrate a mélange: Bowie knives and revolvers meld in a temporal blur with "automatic carbines." And at all times there looms the threat that "a time warp dumps an old western posse in their laps" (218). It is in the logic of the thing that this posse marches naked; what uniforms could they possible wear? The parodic playfulness of this literary strategy is evident in the ritual murder of several horses and boys, ending with the refrain from Vaughn Monroe's 1949 Western hit, "Ghost Rider's in the Sky": "Yipeayee Yipeaayoo Ghost riders in the sky" (238). This song was sung by Gene Autry in his film Riders in the Sky the same year. So, even in comic irreverence, combined with buggery, murder and debauchery, the first novel of the trilogy intimates both the structural exigencies in which the Master Film metaphor 
would be right at home, as well as priming further more direct references for the genre Western.

11 The second novel, The Place of Dead Roads, is arguably the most centered of any extended Burroughs work; and this centering facilitates the illustration of the issues of representation on the macro-level of cultural myth metanarratives. The articulation and subsequent destruction of what is presented as the reigning American master narrative, that of the frontier west, is problematized in a fashion that exposes the enchanting power of myth to naturalize and provide a culturally contingent telos for a culture. As critics who focus on myth have described, the crystallizing kernel of cultural myth frequently comes from within a scholarly discourse, say science or history, that, through repetition and steadily broadening application, as well as an emphasis on image and vignette (icon and trope), is steadily emptied of history and rather articulated as story/fable with the authority, or more so, of the original narrow discourse. ${ }^{3}$ On one level, The Place of Dead Roads participates in the mythology of the American West without irony. At root, this narrative is one of the self-actualization of protagonist Kim Carsons and the attempted liberation of his gang, the Johnsons, from the forces of hegemony and imposed conformity. Burroughs's conflict-and Carsons'sis how to recapture mythological space without becoming hopelessly mired within it. This counter narrative of the mythic west is a re-inscription, a reclaiming of a role in the national heritage that has been denied by historical discourse. But at the same time, as a genre Western, some articulations of action, settings, and characters also function on the level of parody. Indeed, Joe the Dead's denigrating comments about Kim Carsons after he kills him (Western 26), indicate that from that perspective in particular, the parody contributes to a satiric charge. By significantly re-inscribing the mythology of the American West, as a variety of anti-Western, The Place of Dead Roads serves to alter the typical historiographic reading of the "winning of the west."

Specific elements redolent with history and historicity, either as artifacts, episodes or characters, serve to reclaim the mythic space through a routine of re-authentication. First, the protagonist himself, Kim Carsons, is historically embedded; his name is recognizably similar to the "frontiersman" Christopher "Kit" Carson. Mention of the novel's main character in the essay "Creative Reading," has his name "Kim Carson," with a variance of a single letter between the historical figure and the fictional one (42). In The Place of Dead Roads, an extra "s" has been added to the surname. Since Carsons is also the nom de plume of a character within the trilogy, William Seward Hall, an author of Westerns, the mythology orbiting the historical figure Kit Carson is also present as the subject of Western biographies and several dime novels (Slotkin, Fatal 191-92, 198-207). Given Kit Carson's biographical details, he strikes one as an unlikely analogue for a Burroughs hero. His fame is largely derived from his military career in the Mexican-American War, and later in the American Civil War, where his work in the West culminated in "relocating" Apache and Navajo, the latter via the infamous "Long Walk" (Milner 180-81). But as a hero of the mythic west, there are some aspects that do recommend him. Kit Carson has taken on the mythic mantel of frontier hero from Daniel Boone and the fictional Hawkeye in James Fennimore Cooper's novels; "Carson's brand of safe and traditional adventure [...] renews the idea of finding social salvation in the conquest of the wilderness" (Slotkin, Fatal 202). While Kim Carsons certainly seeks some sort of "salvation" in his Western adventures, it is as an anti-Kit CarsonBurroughs's hero is not an Indian fighter any more than he is a willing lackey of 
economic exploitation of the wilderness. But nevertheless, like Kit Carson, it is principally in the West, and a mythologized West at that, that Kim Carsons comes into his own and maintains a high degree of success.

The potential of this mythic space is highlighted by Kim's moving to Saint Albans. Saint Albans is the transformative space in Kim Carsons's development, for it is here he decides to become a shootist in the West instead of an artist in the East. The first time he puts on his .38 (with the ahistorical Mexican clip holster, inside the pants) he almost quakes with his potential power, and he certainly projects it (Place 45-57). Making the American West the locus of self-actuality is surely in line with the Frontier myth, but the trajectory of character development-Kim becomes an openly gay shootist-is unorthodox, to put it mildly. "Identify yourself with your gun," Kim writes in his diary (67). The auto-injunction to identify with the weapon is essentially an act of borrowing the historicity of the artifact. But in retelling the myth, this influence does not flow just one way. The figure of Kim Carsons, gay shootist and outlaw, will also contribute to the historicity of his weapons of choice. While a cult of weapons technology is evident in the whole trilogy, the diverse sidearms in The Place of Dead Roads regularly invoke specific historical and literary associations, but always with a plot element that estranges the reading. ${ }^{4}$

Burroughs's mythic west here represents a refuge, in which the myth can be rewritten to include the typically excluded. This is also evident in Kim Carsons's gang, called the "Wild Fruits," in which the clichéd hyper-masculinity and virility of men in the Western is challenged. The formation of the gang occurs in plotted stages. Billy Chung, Chinese, rescues Carsons in a bar fight (77); Red Dog, an Indian, tags along with Kim from Saint Albans, Tom Dark, the photographer, and Pecos Bridge Juanito join him on the way. The characters are typical bit players in a "wild west" cast, but unusual for a Western, here they are favorably empowered as gay Indian, gay Chinaman, gay frontier photographer, gay Mexican.

This rewriting of the myth is strengthened by re-inscribing historical figures into the story. For instance, the law man Bat Masterson briefly functions as a mentor for Kim, and essentially aids him in finding his place in the historical tensions of Gilded Age rapine (75-76). Masterson, the legendary gambler and lawman takes a paternal interest in the young Carsons, and always evinces respect; he tells him that "In this life you have to fit in somewhere" (76). Kim is even offered the job of deputy. Masterson also suggests that Kim join an outfit "Taking care of sodbusters," possibly invoking the historical homesteader versus cattle driver conflict, mythologized in Shane. During another saloon conflict, bystander Pat Garrett again places Kim Carsons within history by extra-textual referencing of a "real" historical figure. These intrusions of the extratextual is of a different kind than the reference to Kit Carson; Masterson and later Pat Garrett, while known figures of the West, are not full-fledged Western heroes; their presence is historical. This lends a degree of credence to Kim's development, while at the same time helping to underwrite a re-inscription of an alternative mythology.

The last element I will discuss here has to do with the bearer of the ethical charge of the work, the "Johnsons." By now, the origin of this term in the Cities of the Red Night trilogy is well known. According to the author's introduction, the original title for the The Place of Dead Roads was "The Johnson Family." Derived from an account of the petty criminal underworld, You Can't Win by Jack Black, "A Johnson minds his own business. But he will help when help is needed" (n. pag.). And herein lies the normative ethos for 
which the Johnsons stand: non-interference and a helping hand when absolutely necessary, a basic anarcho-liberal position without any ideological dross, "a Manichean position where good and evil are in conflict and the outcome is at this point uncertain" (Burroughs, "The Johnson Family" 74).

17 One would be justified to pursue the significance of the Johnsons no further, except for repeated references to the homesteader versus cattle-grower conflict and to Owen Wister's The Virginian. Wister, one time manager of a Wyoming cattle concern, based some of the episodes in his novel on the 1892 "Johnson County War," and the Virginian himself embodies the stern vigilantism of Eastern and European capital's ruthless "incorporation" of the Western lands of the United States. While not the bloodiest of the conflicts, Wyoming's Johnson County War is arguably the best known due to the pronounced political solidarity of the Grange and Populist Parties with the Democrats, arrayed against the corporatist concerns of the Wyoming Stock-Growers Association in league with Republicans in the U.S. Senate and the White House. Also, at the outset of the war in 1892, the hired vigilantes in fact lost the first battles, exposing the ruthless machinations against the small scale ranchers, justified by exaggerated claims of "rustling" (Brown 396, 402-03; Slotkin, Gunfighter 172-76).

Burroughs has directly written in The Virginian, and by historical association, the Johnson Family's historical analogue to the aggrieved party in the Johnson County War is exposed. Also, recalling that Carsons is the pen name for author Hall, the Wister / Virginian relation of author / protagonist is mirrored by the Hall / Kim Carsons connection. Kim Carsons is ironically framed as the Progressive Era frontier hero in mimicking the Virginian's performing vigilante justice: "Kim stands there all squarejawed and stern and noble like the Virginian getting set to hang his best friend for rustling the sacred cows on which the West is built" (Place 135). This is Kim's pose as he is about to kill some dogs because they have attacked livestock. Burroughs's use of intertextuality adds an interpretive tension to the reading, for even though Carsons is in the function of the lawman, he is-as was the Virginian-here a vigilante, but with a difference. In The Virginian,the protagonist displays a stoical detachment before executing his old running mate, Steve, but evinces remorse over the situation afterwards, indeed "He gave a sob" (Wister 260). But Carsons here merely plays a role as Burroughs plugs him into Wister's narrative stream that is part of the Myth of the American West. And in the normative ethos suggested by the Johnson County War (and the Johnson Family), he is on the wrong side. In truth, Carsons is not interested in practicing vigilante frontier justice; his concern is not in cattle: "Who cares about fucking cows" (Place 135). Burroughs adopts and plays off of the literary trope that is part of the mythology of American identity.

19 While most the articulations of the mythic west are conscious, deliberate artistic decisions, there is at the meta-level of the Cities of the Red Night trilogy an assumption, specifically stated in the preface of The Place of Dead Roads, that "[t]he only thing that could unite the planet is a united space program" (n. pag.), ultimately aimed at offplanet migration. Alex Houen has insightfully grasped the allure of space migration for Burroughs, arguing that he "increasingly fashions his mythology as a pointed literary alternative to specific aspects of the space programmes-which he came to see as exemplifying networked strictures of what others have termed 'postmodern' culture" (525). If it is the case that Burroughs's intention with this prominent space migration subtext "amounts to writing a counter-postmodernism" (526), the alternative present 
in this trilogy, at any rate, bears a strong testament to the persistence of cultural myth. Here, and in his advocacy, Burroughs is uncritically adopting the interplanetary frontier as an analogue of the Western Frontier, insofar that they both share a "safetyvalve" function. Henry Nash Smith characterizes the "safety valve theory" as a major justification for the Homestead Act, to bleed out the radicalism of the congested laboring masses that may agitate and create unrest in the East by offering them sustenance in the West (168-71). Unlike the social potentialities of "Outer Space" narratives detected by Houen in Burroughs's opus, the mythic west in The Place of Dead Roads only partially fulfills its safety valve / haven function. And by relying on it overmuch, Kim Carsons is won to his doom. To see how, the phenomenon of the Master Film must be scrutinized, for it is both Kim Carsons's familiarity with the Western and reliance upon it that enables him to come as far as he does. The Western here is shown to function as a "Master Film," and more to the point, by playing off of the mythologizing function, Burroughs positions Carsons so that he is aware enough to try to resist the naturalizing power of cultural myth, though ineluctably seduced by it in the end.

\section{He Who Lives by the Myth, Dies by the Myth}

Something like the Master Film has been with Burroughs since Naked Lunch. The Great Slushtubitch's pornographic film featured in "A.J.'s Annual Party" has as its aesthetic and ethical base the insuperable goal of attaining and maintaining the genuine. The Director Slushtubitch declares that those who would fake an orgasm, or act in the thespian sense were ruthlessly rejected (75). And after this film goes thorough its requisite reels, the actors seem very much the worse for wear: "They are not as young as they appear in the Blue Movies. ... They look tired and petulant" (87). The image here is one of these hapless individuals trapped in a variety of "Master Film," doomed again and again to repeatedly unfurl their desire as senseless sex acts and executions. Kim Carsons has come considerably further, for he is uniquely capable of perforating, rupturing and potentially altering the Master Film. This is clearly depicted on three occasions in the narrative: in the first chapter shoot-out in the Boulder Cemetery, in the ambushes against the Wild Fruits, and in an all-night writing jag in Tangiers, during which Hall / Carsons as author is imbued with a sense of the reality of the Master Film.

The Place of Dead Roads begins and ends with two versions of the same event separated by the entire narrative, a shoot-out in the Boulder Cemetery between bounty hunter Mike Chase and Kim Carsons on September 17, $1899(6,306)$. At the outset of the first chapter, there is a newspaper article that includes an enigmatic mystery: in spite of both men being dead, "neither gun had been fired" (3). However, the events as depicted in the journalistic discourse are belied by the rest of the first chapter: Kim Carsons and Mike Chase indeed do fire their weapons. Carsons points his empty hand at Chase and shouts "BANG! YOU'RE DEAD," whereupon Chase's hurried shot misses Carsons to the left; Carson draws his pistol and his bullet "hits Mike just above the heart" (7). After killing Chase, Carsons attacks the Master Film, rending the very fabric of existence. A hunter is singing Harold Arlen's "It's only a paper moon," implying that the literal setting of the shoot-out is fake, but-in line with the lyrics of the song-it would be real "if you believe in me." The reality is implicitly sustained by belief, but Kim is not buying it: he perforates the moon, "a grove of trees at the end of the cemetery," and ignoring the warnings of "the spurious father figures that rush on stage," the sky (8-9). This rip 
in the Master Film may indicate a narrative track in which Carsons's gang, the Wild Fruit (Johnsons to the man), succeed in the ultimate escape from the forces of their oppression. However, at the replaying of this same episode at the conclusion of the book the reader is presented with a different series of events, corroborating the newspaper article on the first page: Carsons and Chase are struck down dead by two bullets from a high-powered rifle, neither of their weapons have been discharged (306). It is of moment that the Master Film is only mentioned when it is riven by Carsons in the first version of this shootout. When the action runs as the Director wishes, the narrative is seamless.

21 The key to the Master Film metaphor lies in its twin qualities of standing for, and functioning as, a cultural myth master narrative, and at the same time being repeatable. Returning to Slushtubitch's pornographic oeuvre from Naked Lunch, the petulance of the actors can be derived from the tiring repetitions. However, Kim's successful killing of Mike Chase at the outset, followed immediately by his turning his master narrative derived shootists talents on the master narrative / Master Film itself bears witness to the extreme degree of personal empowerment that Carsons has derived from adopting the Western mythology for his own. But, every film has a director, and this one is no exception. Carsons's success, gained by identifying himself with the self-actualizing potential of the mythology of the American West, ultimately seals his fate. In the final run of this scene, he is killed. In this reading of the mythic west, it serves to entrap Kim Carsons in the Western Master Film until the powers-thatbe can finally dispatch him. But Carson's removal is not effected until the last page.

The Master Film metaphor is developed first with fine arts cues, comparing Dodge City to el Greco's Toledo, and then in terms of cinema in which "dead streets of an old film set" (73) supports the diverse "pre-recordings" channeled in part by the Western. Throughout The Place of Dead Roads, there is the promise that Kim Carsons may be able to master the Master Film. Tom Dark, the photographer, provides some explanation as to how this might be achieved. His comment that "All pictures are faked" serves as ostensive evidence of the old semiotics saw that everything that represents can also lie: "As soon as you have a concept of a picture there is no limit to falsification" (84). Dark carries the analogy further to the Master Film because "He is looking forward to moving film" (88). Says he, in a carny rant: "We attempt the impossible: to photograph the present moment which contains the past the future. All art attempts the impossible. Consider the problem of photographing past time" (89). Tom Dark thus exposes the logic of the Master Film, and opens up the possibility of manipulation and falsifying, especially in the action of simulating the mass death of Carsons's clan. After a brief newspaper clipping on the Wild Fruits, the US Army is called in to deal with them, only to find the Fort Johnson hold-out abandoned by the living and left to the dead. The headline "MASS SUICIDE OR MASSIVE HOAX?" (110) leaves open the escape of the Johnsons suggested by Kim's breaching the Master Film at the start of the novel. And a token of his potential to master the Master Film occurs in the successful aversion of catastrophe for Kim's gang in the first Manhattan Ambush.

The explanation of the Master Film comes in connection with an ambush that starts out in a Manhattan gangster milieu and then is replayed in Wild West fashion with hired gun Mike Chase setting them up in the false-fronted town of Manhattan, New Mexico, itself analogous to a film set. When Kim's gang wipes out an attacking Mafiosi gang in New York, this successful escape triggers a reaction from the Director, a half-page 
diatribe in italics. The important point is that the Master Film and the pre-recordings that compose them are revealed to be a zero-sum system. If one insert too many prerecordings that are totally fabricated, the Director explains,

Then the bottom falls out and you start springing leaks in the Master Film ... like this Carsons thing. ... Boss wants to hit him. I film it. Carsons and his boys kill the

hit men ... and every time he slides out from under, he cuts the film .... (177)

The "Technician" presses the appropriate button, and conjures up another attack, "THE MANHATTAN AMBUSH." And while the preceding Master Film was composed of "Old gangster film stock" (176), this one is a Western.

This replaying of the ambush now takes place in the Frontier West. The Johnsons in their Wild Fruits manifestation are "riding south for Mexico because [they] all have eagles on their heads" (180). But Kim and others of the gang require junk, so against Tom Dark's better judgment, they enter the town. At once they are taken with its artificial mundanity, and Kim realizes that something is not quite right, but too late. In this run of the Master Film there are several casualties, chief among them Tom Dark. In spite of the power the mythic west has given Kim Carsons, the Master Film as Western also exerts a more coercive force: in the New York Gangster scenario, no one dies; in the New Mexico Western, several do.

A further embellishment and explanation of the Master Film comes in the third part of The Place of Dead Roads, "Quién es?" where Kim the Shootist of the mythology of the American West has morphed into an intelligence operative in Arabia. The most striking feature of this chapter is the explanatory passage typed by Kim till the wee hours of the morning, set off by indentation. It is a cosmology, of sorts, of a "magical universe" in which the Christian God and Allah are likened to colonial parasites on the human race. Kim's extended rumination contains a surprisingly thorough, if enigmatic, "didactic" presentation of the Master Film. The first step in evolving off of Earth is to "See human history as a vast film spread out in front of you [...]. You are God for that film segment. So 'God,' then, has precisely that power with the human film." The next paragraph begins with the apparently self-contradictory assertion that "The only thing not prerecorded in a prerecorded universe is the prerecordings themselves: the master film." One possible interpretation of this koan-like utterance is that Burroughs imbues the Master Film with an origin and permanence of a higher order than a pedestrian use of the term "prerecording" would imply, at least for the Director. If they are in fact not prerecorded, they assume the role of timeless, eternal, time-sequences that impose or facilitate the playing out of a mythic plot. And that, precisely, is the story that we are to witness in The Place of Dead Roads:

The unforgivable sin is to tamper with the prerecordings. Exactly what Kim is doing. Acting through his representatives like Hart and old Man Bickford, God has prerecorded Kim's death. (218)

The Master Film is a Western, but one that Kim himself partially masters:

“WHO IN THE FUCK IS THAT IN MY FILM?" the Director bellows. "GIVE HIM THE TREATMENT."

So they did and it backfired. Kim grins out between his legs and fires. His bullet takes out the water tower, half a mesa, a piece of sky .... (219)

And, as in the first version of the shootout in Boulder, Kim's pistol tears the fabric of the Master Film. Kim's disruption of the Master Film serves Burroughs's theory of literature's coming to be more concerned with space than time (Morgan 340), but it also sets up two distinct points of view: one in which Kim Carsons at the outset 
succeeds in disrupting the Master Film, and another in which the entire rest if the novel is one long replaying of the Master Film, ultimately affording Carsons no escape.

The Place of Dead Roads, then, makes most use of a single metanarrative, the mythology of the American West, largely via the Western. The final book of the trilogy, The Western Lands, unseats this hegemonic metanarrative and offers a less centered assortmentbased for the most part on Egyptian mythology and religion, the implicit cosmology of the previous two books, and other pieces by Burroughs. Reminiscent of its treatment in Cities of the Red Night, the inclusion of the mythic west is by way of citation, for example the episode with deputy sheriff Zed Barnes (Western 148-50) and the brief appearance of John Wayne as avenger from the film Red River (174).However, in the novel as a whole, the American West is contrasted with the eternal verities of the Western Lands of Egyptian mythology. The Western Lands is Paradise, but the American West is earthly, mundane, and in fact ultimately lost. None the less, when the narrator in The Place of Dead Roads brazenly announces that the Johnson-inspired Wild Fruit are going to take over the Western Lands, Paradise does not sound like it is on the agenda:

No one can apply unless he breathes in a writer's prose hills and faraway Western

Lands. ...

Radiant heroes, storm the citadel. ... Kill the last guards and walk.

Guns glint in the sun, powder smoke drifts from the pages as the old West goes

into a penny-ante peep show, false fronts, a phantom buckboard. (Place 202)

The first paragraph indicates that the elect (the Johnsons) will absorb the meme, "writer's prose," which is then juxtaposed to the gun smoke in the last paragraph. The "writer's prose" is the conduit to the Western Lands, "smoke drifts from the pages," and the old West of the Western is transformed, but into a false West, a caricature of itself, "penny-ante peep show."

Why, then, is it necessary to assassinate Kim Carsons? Carsons's death is the main hook connecting The Place of Dead Roads with the final novel, The Western lands, where it is revealed that the Sekem "technician," Joe the Dead dispatched both Carson and Chase:

No regrets about Kim. Arty type, no principles. And not much sense. Sooner or later he would have precipitated a senseless disaster with his histrionic faggotries ... chessmen to be removed from the board, perhaps to be used again in a more advantageous context. (Western 26)

Carsons in The Place of Dead Roads incarnation was a loose canon on deck: "Joe didn't have ideas about rewriting history like Kim did. More of Kim's irresponsible faggotry: he's going to rewrite history while we wait" (Western 59). Kim, then, is the only one who has come close to rupturing the Master Film, having almost done so three times. And if he does finally succeed in its final destruction, he may succumb to the temptation to reimpose his re-vamped mythology of the American West as a dominant cultural myth. How appropriate, then, that it is, after all, in a Western that the Director finally succeeds in killing the potential corrupter of the Master Film. The literary effect (and possibly the intention) is to flirt with a metanarrative that comes dangerously close to imposing a totalizing order, and it is within the totalizing order of the Western that the liberatory figure of Kim Carsons is first actualized and liberated, and eventually laid to rest. The film is not seamless, and there is room for manipulation. And the mode of the portrayal is not a completely bleak one: Carsons does return as the author Hall in The Western Lands when his "chesspiece" is returned to the board. Because there is a high degree of thematic focus in The Place of Dead Roads, the Master Film is easily borne on the back of the cultural myth master narrative, the Western. Yet, the novel begins and 
ends with a permutated shoot-out, indicating that a cliché has been twisted-the Master Film (that is the novel) is changed for deliberate artistic effect, run one way in the beginning, and quite another in conclusion. By this, all teleological narratives, carried ineluctably on any stable narrative, are shown to be inherently dangerous. The mythic west in this book, then, invokes a dogma, a telos; it is too powerful, and its representative has to be taken out. Kim Carsons is assassinated for taking over the Master Film. William S. Burroughs's liberation program can not (and will not) favor a single myth. In this regime, after they perform an essential organizing function, the myths themselves are expendable.

\section{BIBLIOGRAPHY}

Barthes, Roland. Mythologies. New York: Hill and Wang 1972.

Brown, Richard Maxwell. "Chapter Eleven: Violence." The Oxford History of the American West. Ed. Clyde A. Milner II, Carol A. O'Connor, and Martha A. Sandweiss. Oxford: Oxford University Press, 1994. 393-425.

Burroughs, William S. The Adding Machine: Selected Essays. New York: Arcade, 1993.

-- . Cities of the Red Night. New York: Holt, Rinehart and Winston, 1981.

-_- "Creative Reading." Burroughs, The Adding Machine 37-46.

---. “The Johnson Family." Burroughs, The Adding Machine 73-76.

-_-. "Les Voleurs." Burroughs, The Adding Machine 19-21.

---. Naked Lunch: The Restored Text. New York: Grove Press 2001.

-- . The Place of Dead Roads. New York: Holt, Rinehart and Winston, 1983.

“Technology and Writing." Burroughs, The Adding Machine 32-36.

---. The Western Lands. New York: Viking 1987.

Glover, David. “Burroughs' Western.” William S. Burroughs At the Front: Critical Receptions, 1959-1989. Ed. Jennie Skerl and Robin Lydenberg. Carbondale, IL: Southern Illinois University Press, 1991. 209-15.

Houen, Alex. "William S. Burroughs's Cities of the Red Night Trilogy: Writing Outer Space." Journal of American Studies 40.3 (2006): 523-49.

Kolodny, Annette. The Lay of the Land: Metaphor as Experience and History in American Life and Letters. Chapel Hill: University of North Carolina Press, 1975.

Marx, Leo. The Machine in the Garden: Technology and the Pastoral in America. 1964. New York: Oxford UP, 2000 .

Milner II, Clyde A. "Chapter Five: National Initiatives.” The Oxford History of the American West. Ed. Clyde A. Milner II, Carol A. O'Connor, and Martha A. Sandweiss. Oxford: Oxford University Press, 1994. 155-93. 
Morgan, Ted. Literary Outlaw: The Life and Times of William S. Burroughs. London: Boodle Head, 1991.

Murphy, Timothy S. Wising Up the Marks: The Amodern William Burroughs. Berkeley: University of California Press, 1997.

Reising, Russell J. The Unusable Past: Theory and the Study of American Literature. New York: Methuen, 1986.

Slotkin, Richard. The Fatal Environment: The Myth of the Frontier in the Age of Industrialization 1800-1890. 1985. New York: HarperCollins, 1994.

---. Gunfighter Nation: The Myth of the Frontier in Twentieth-Century America. New York: Athenaeum, 1992.

Smith, Henry Nash. Virgin Land: The American West as Symbol and Myth. 1950. Cambridge, MA: Harvard University Press, 1978.

Weisenburger, Steven. Fables of Subversion: Satire in the American Novel 1930-1980. Athens, GA: University of Georgia Press 1995.

Wister, Owen. The Virginian: A Horseman of the Plains. Oxford: Oxford University Press 1998.

\section{NOTES}

1. William S. Burroughs, Cities of the Red Night (1981); William S. Burroughs, The Place of Dead Roads (1983); William S. Burroughs, The Western Lands (1987).

2. Formative milestones in this aspect of the "American Myth and Symbol School" are Henry Nash Smith's Virgin Land: The American West as Symbol and Myth (1950), Leo Marx's The Machine in the Garden (1964), and Annette Kolodny's The Lay of the Land: Metaphor as Experience and History in American Life and Letters (1975), among others. For a critique of this type of ideologically contingent approach, which includes that of Richard Slotkin, see Russell Reising, The Unusable Past: Theory and the Study of American Literature (1986).

3. The most influential expression of this perspective on "myth criticism" is Roland Barthes's essay "Myth Today." Richard Slotkin adopts this approach, albeit in a somewhat qualified fashion, in The Fatal Environment, and continues in Gunfighter Nation. See Roland Barthes, Mythologies 109-59; Richard Slotkin, The Fatal Environment 11, 13-32.

4. For example, see the comical vignettes on pp. 65-66 with "the 44 Russian" where Carson is in a sleigh firing at wolves right out of a Tolstoy novel, only he rewrites this script by sacrificing the Countess to the pack. When he first tries out the 32-20, a more typical "Western" sidearm, he for the only time ever replays the trope of the lawman against a stagecoach bandit. Yet, in doing this, he notices "it doesn't seem to have the élan of the others" (66).

\section{ABSTRACTS}

This essay traces the vestiges of Western literary and cinematic tropes in Cities of the Red Night, and discusses the development of the Master Film and the dominance of the Western genre in The Place of Dead Roads and some faint echoes of the mythology of the American West in the last 
book, The Western Lands. The dubious enchantment of cultural myth dominates the Cities of the Red Night trilogy, but particularly the second novel, The Place of Dead Roads, demonstrates that the myth of the American West serves both the powers of hegemony and resistance. In The Place of Dead Roads, the Master Film is unequivocally the Western, centered as it is on the shootist Kim Carsons as the "hero." His tactic in his liberatory struggle is the warping, splicing and destruction of the narrative myth fabric, developed metaphorically as the "Master Film," providing as it does a critique of the Western as reigning American cultural myth, as well as questioning the psychic or cognitive hegemony of any cultural myth.

\section{INDEX}

Keywords: Cities of the Red Night, Cities of the Red Night trilogy, history and myth, Master Film, mythology of the American West, The Place of Dead Roads, The Western Lands, Western genre

\section{AUTHORS}

\section{MICHAEL J. PRINCE}

University of Agder, Norway 